Contract No. and Disclaimer:

This manuscript has been authored by Savannah River Nuclear Solutions, LLC under Contract No. DE-AC09-08SR22470 with the U.S. Department of Energy. The United States Government retains and the publisher, by accepting this article for publication, acknowledges that the United States Government retains a non-exclusive, paid-up, irrevocable, worldwide license to publish or reproduce the published form of this work, or allow others to do so, for United States Government purposes. 


\title{
Fundamental Environmental Reactivity Testing and Analysis of the Hydrogen Storage Material $2 \mathrm{LiBH}_{4} \cdot \mathrm{MgH}_{2}$
}

\author{
Charles W. James Jr, Kyle S. Brinkman, Joshua R. Gray, \\ Jose A. Cortes-Concepcion \& Donald L. Anton* \\ Savannah River National Laboratory \\ Aiken, SC, 29808 USA, \\ *Corresponding Author: Tel: +1 803-507-8551, Fax: +1 803-652-8137 \\ Email: donald.anton@srnl.doe.gov
}

\begin{abstract}
$\underline{\text { Abstract }}$
While the storage of hydrogen for portable and stationary applications is regarded as critical in bringing PEM fuel cells to commercial acceptance, little is known of the environmental exposure risks posed in utilizing condensed phase chemical storage options as in complex hydrides. It is thus important to understand the effect of environmental exposure of metal hydrides in the case of accident scenarios. Simulated tests were performed following the United Nations standards to test for flammability and water reactivity in air for a destabilized lithium borohydride and magnesium hydride system in a 2 to 1 molar ratio respectively. It was determined that the mixture acted similarly to the parent, lithium borohydride, but at slower rate of reaction seen in magnesium hydride. To quantify environmental exposure kinetics, isothermal calorimetry was utilized to measure the enthalpy of reaction as a function of exposure time to dry and humid air, and liquid water. The reaction with liquid water was found to increase the heat flow significantly during exposure compared to exposure in dry or humid air environments. Calorimetric results showed the maximum normalized heat flow the fully charged material was 6 $\mathrm{mW} / \mathrm{mg}$ under liquid phase hydrolysis; and $14 \mathrm{~mW} / \mathrm{mg}$ for the fully discharged material also occurring under liquid phase hydrolysis conditions.
\end{abstract}

Keywords: hydrogen storage, environmental reactivity, lithium borohydride, magnesium hydride, calorimetry 


\section{Introduction}

The storage of hydrogen in a volumetrically and gravimetrically dense form must be met for the realization of hydrogen powered light duty vehicles. There have been numerous studies focused on understanding the sorption kinetics, hydrogen capacity and structures of the three primary types of complex metal hydrides: alanates[1-3], borohydrides [4-6], and amides [7-9]. However, there is very little understanding of the potential environmental exposure risks associated with implementing these materials. Therefore, it is important to understand and quantify these risks in the case of a storage tank being breached and the hydride material exposed to conditions such as dry air, humid air, liquid water and simultaneous water/air contact.

There are a number of recent publications that have begun to explore the risks of environmental exposure of catalyzed $\mathrm{NaAlH}_{4}$ and similar mateirals materials [11-13] which have been used in kilogram quantities in laboratory demonstrations of stoprage systems. In these studies, liquid or gaseous water contact has been identified as leading to the most vigerous reactions resutling in hydrogen gas releas and heat generation. The controlled hydrolysis of chemical hydrides such as sodium borohydride have been studied for hydrogen generation, however much less is understood about uncontrolled hydrolysis and oxidation under accidental environmental exposure scenarios. For example, the oxidation behavior of alkali hydride $\mathrm{LiH}$ has been investigated [19] focusing on trace amounts of $\mathrm{O}_{2}$ and $\mathrm{H}_{2} \mathrm{O}$ reactants which can oxidize the $\mathrm{LiH}$ surface and inhibit the material from its role in successfully reacting with ammonia gas generated from lithium amide decomposition. Concerning studies focused on the safety of materials and properties for engineering storage systems, a report written by Dedrick [20] compiled data on the sodium alanate, $\mathrm{NaAlH}_{4}$, system including the identification of gas and solid products resulting from air and water exposure. 
This paper will focus on another chemical hydride system which has been shown to be reversible; a mixture of lithium borohydride $\left(\mathrm{LiBH}_{4}\right)$ and magnesium hydride $\left(\mathrm{MgH}_{2}\right)$ in a molar ratio of 2 to 1 , respectively. Vajo et al[14] showed that the formation of $\mathrm{MgB}_{2}$ during dehydrogenation reduced the enthalpy of reaction making the material reversiable at 1-10 bar and $20-100^{\circ} \mathrm{C}$. The "destabilized" mixture has been reported to have a $>10 \mathrm{wt} \% \mathrm{H}_{2}$ capacity. [14, 15]. The reversible chemical reaction was given as:

$$
\mathrm{LiBH}_{4}+1 / 2 \mathrm{MgH}_{2} \leftrightarrow \mathrm{LiH}+1 / 2 \mathrm{MgB}_{2}+2 \mathrm{H}_{2}
$$

This paper will outline the results of a series of tests following the United Nation procedures for testing of water reactivity and flammability testing. In addition to these qualitative experiments, a quantitative assessment of the rate of heat released during air and water exposure were undertaken utilizing a Calvet calorimeter.

\section{Experimental Details}

\subsection{Material Preparation}

The starting materials, lithium borohydride ( $\geq 90 \%$, Sigma Aldrich) and magnesium hydride ( $>95 \%$, Alfa Aesar) were purchased and used as-received. Approximately three grams of the 2:1 molar mixture of $\mathrm{LiBH}_{4}: \mathrm{MgH}_{2}$ were loaded into a milling jar within an argon filled glove box. The samples were prepared using a Spex mill for 1 hour. A ball-to-sample ratio of $20 \mathrm{gm}$ to $3 \mathrm{gm}$ was maintained for all samples.

\subsection{U.N. Testing}

A set of materials testing procedures was developed based on internationally accepted United Nations testing procedures [21]. These tests include exposure to laboratory air, and liquid water and fully described in the following sections. These U.N. test procedures were modified by inclusion of thermocouples to monitor the temperature in proximity to or within 
the test material, All tests were video recorded for later analysis and comparison.

\subsubsection{Water Reactivity}

The purpose of the water reactivity test is to identify if the substance, when in contact with water, burns or emits flammable gases. If spontaneous ignition occurred at any stage, the substance is classified as a water reactive substance emitting flammable gases. The experimental details followed UN-RTDG part-3, test-N5 in which three separate tests were conducted. (i) The test substance was formed into a small uniform pile approximately $20 \mathrm{~mm}$ high and $30 \mathrm{~mm}$ diameter with a hollow in the top to catch water. A few drops of water are added to the hollow with a pipette. (Water Drop Test) (ii) A small quantity (approximately $2 \mathrm{~mm}$ diameter) of the test substance was dropped in a beaker of distilled water at $20^{\circ} \mathrm{C}$. (Water Immersion Test) (iii) A small quantity (approximately $2 \mathrm{~mm}$ diameter) of the test substance was placed on the center of a filter paper which is floated flat on the surface of distilled water at $20^{\circ} \mathrm{C}$ in a $250 \mathrm{ml}$ beaker. The filter paper keept the substance simultaneously in contact with water and air, under which the likelihood of spontaneous ignition of any evolved gas is greatest. (Surface Contact Test)

\subsubsection{Flammability Test}

\section{Burn Rate Test}

The purpose of the burn rate test is to classify rapidly combustible solids by differentiation between ignitable, rapid burning and dangerous burning substances and to assess the relative hazards of rapidly combustible solids. The test procedure details followed UNRTDG part-3, test-N1. The sample material was deposited as a strip on a platform to measure the burning rate. The strip $250 \mathrm{~mm}$ in length and $100 \mathrm{~mm}^{2}$ cross-section was ignited from one end and the burn propagation time measured for $100 \mathrm{~mm}$ after an initial stabilization period. A series

of 6 thermocouples were fitted along the powder strip length at regular intervals, so that the 
temperature approximately could be monitored as a function of time. Additionally, these tests were video recorded to provide qualitative data acquisition, as well as to calculate the burn rate.

\section{Spontaneous Combustion Test}

This test is conducted in order to determine the susceptibility of a material to spontaneously ignite in air if subjected to an elevated temperature. The details of the test procedure followed UN-RTDG div. 4.2. The powder samples were loaded in $25 \times 25 \times 25 \mathrm{~mm}$ stainless steel mesh baskets with $0.05 \mathrm{~mm}$ mesh openings and an uncovered top surface. Three chromel-alumel thermocouples, with $0.3 \mathrm{~mm}$ diameter were inserted into the cubic sample container at positions in the cube center, face-center, and cube corner to monitor temperature. The basket was housed in a secondary enclosed cubic mesh container also made of stainless steel with a mesh opening of $0.60 \mathrm{~mm}$, and slightly larger than the sample container. The cube was set in a hot air circulating oven nominally at $150^{\circ} \mathrm{C}$ for at least 24 hours or until spontaneous ignition or hazardous self-heating was observed. It was experimentally observed that there was a measured $10^{\circ} \mathrm{C}$ overshoot above the nominal set-point temperature. The changes of sample temperature at the chosen locations of the cube were recorded for the duration of the test. 


\section{Pyrophoricity Test}

The purpose of the pyrophoricity test is to determine the ability of a powder solid to ignite on contact with air and determine the time to ignition. The test procedure followed UN-RTDG part3, test-N2. A 1 2 $\mathrm{ml}$ sample was poured from approximately a one meter height onto a noncombustible surface. Observation was made as to whether the substance ignited during dropping or within 5 minutes of settling. This procedure was performed six times or until a positive result was obtained. The substance was classified as pyrophoric if ignition occurred during one of three free-dropping tests.

\subsection{Calorimetry}

To quantify the heat released through contact with dry and humidified air and liquid water, oxidation and hydrolysis studies were performed in a Calvet calorimeter as described in $[22,23]$ The heat flow ( $\mathrm{mW}$ ) was normalized with respect to a nonexposed hydride and recorded versus time. Liquid water exposure tests were performed using a mixing cell with $1 \mathrm{ml}$ of $\mathrm{pH}$-neutral water to react with 5-10 mg of solid. Controlled humid air reaction measurements were conducted at varying relative humidity levels (30 and 60\% RH) and temperatures (40 and $70{ }^{\circ} \mathrm{C}$ ). For these measurements, the calorimeter equipped with a flow cell utlilizing either argon or air as the carrier gas with a flow rate of $10 \mathrm{ml} / \mathrm{min}$ reacting with $5-10 \mathrm{mg}$ of solid.

There are important experimental differences for the exposure of hydrogen storage materials to water vapor versus liquid water in the calorimetric method used in this study. As graphically depicted in Figure 1a, at time $=0$ s in a liquid water mixing experiment, an excess of 32 times the stoichiometric amount of water was added which remained constant during the duration of the experiment. In contrast, the amount of water added during gas flow experiments was determined by the flow rate, the gas and reaction temperature and thermodynamics of the 
water liquid/vapor equilibrium expressed through the relative humidity indicator. Since water vapor was added in a flow through configuration, the quantity provided for the hydrolysis reaction increased linearly with time. The saturation vapor pressure of water increases with temperature so that higher temperatures and higher relative humidity levels increased the amount of water available for the hydrolysis reaction. Figure $1 \mathrm{~b}$ gives an expanded view of the time to stoichiometric water addition with varying temperature and relative humidity. The temperature of $40^{\circ} \mathrm{C}\left(104^{\circ} \mathrm{F}\right)$ represents conditions on a comfortable $(60 \%$ relative humidity) and dry $(30 \%$ relative humidity) summer day. The higher temperature, $70^{\circ} \mathrm{C}$, was studied in order to estimate the effect of heat from a fuel cell or internal combustion engine operating at elevated temperatures in an accident scenario.

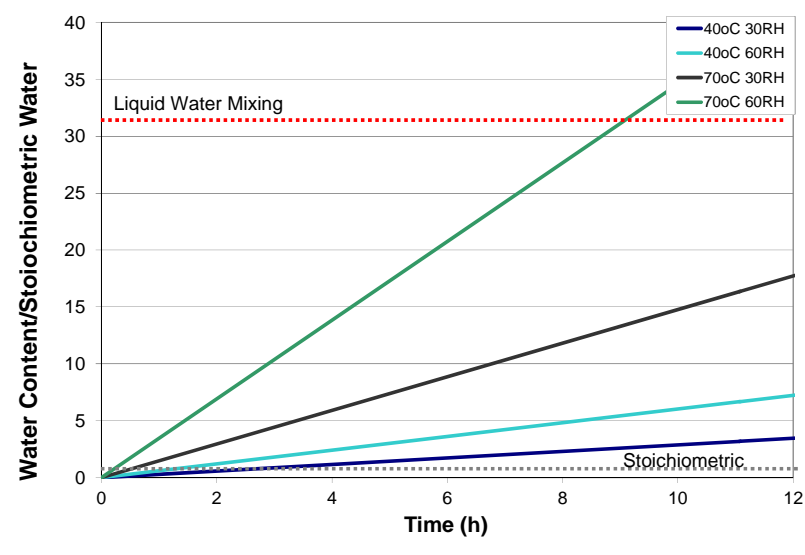

a)

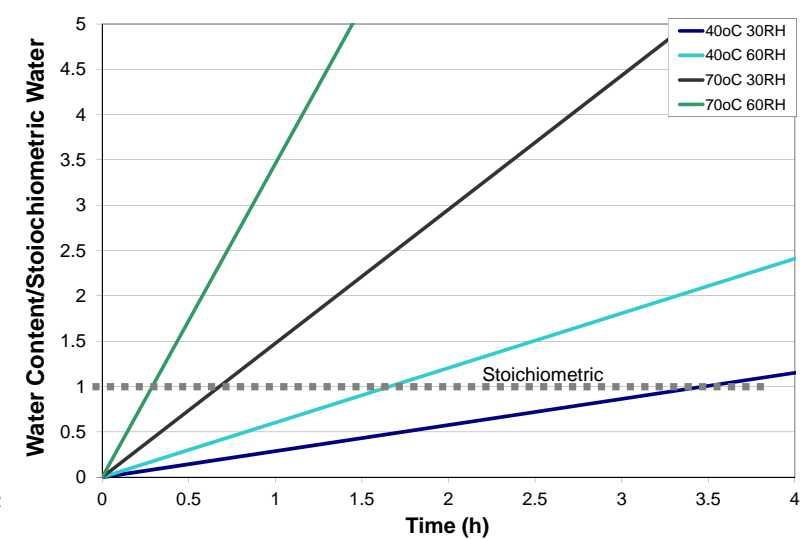

b)

Figure 1 - Water content/Stoichiometric water versus time in hours (h) for gas phase hydrolysis in a flow cell with a flow rate of $10 \mathrm{ml} / \mathrm{min}$ at $40^{\circ} \mathrm{C}$ and $70^{\circ} \mathrm{C}$ with relative humidity levels of $30 \%$ and $60 \%$. For liquid water mixing 32 times the stoichiometric water level is added at $\mathbf{t}=\mathbf{0}$. 


\subsection{Results and Discussion}

\subsection{U.N. Testing}

The pure components, $\mathrm{LiBH}_{4}$ and $\mathrm{MgH}_{2}$, were first subjected to the series of U.N. Testing for water reactivity. It is of importance to understand that $\mathrm{LiBH}_{4}$ is known to be hydrophilic, while $\mathrm{MgH}_{2}$ is known to be hydrophobic. The phobicity affects the extent of reaction that can occur during environmental exposure. Figures 2 and 3, pictorially display the results of the Surface Contact and Water Drop test, respectively, for $\mathrm{MgH}_{2}$ and $\mathrm{LiBH}_{4}$. Keep in mind, the Surface Contact test utilizes the same volume of water used as in the Water Immersion test. The difference is a standard laboratory filter paper that is placed on top of the beaker of water, with direct contact beneath the liquid phase. This has the effect of ensuring that the hydride material is kept in a single location while in contact with the excess of water. Also, it reduces the heat transfer from the location of gas evolution into the water phase, as the material is now surrounded on the top and sides by less conductive air. It can be seen in Figure 2a that after a few seconds of exposure, $\mathrm{MgH}_{2}$ undergoes a reaction event with the water and both the materials and any evolved hydrogen continue to burn for several minutes until the reactants are depleted. In comparison to this behavior, the $\mathrm{LiBH}_{4}$ reacts immediately upon being placed on the filter paper, Figure $2 \mathrm{~b}$, and is observed to be much more reactive than $\mathrm{MgH}_{2}$. The period of time over which the reaction continues is also much shorter, most likely due to the relatively strong reactivity. 

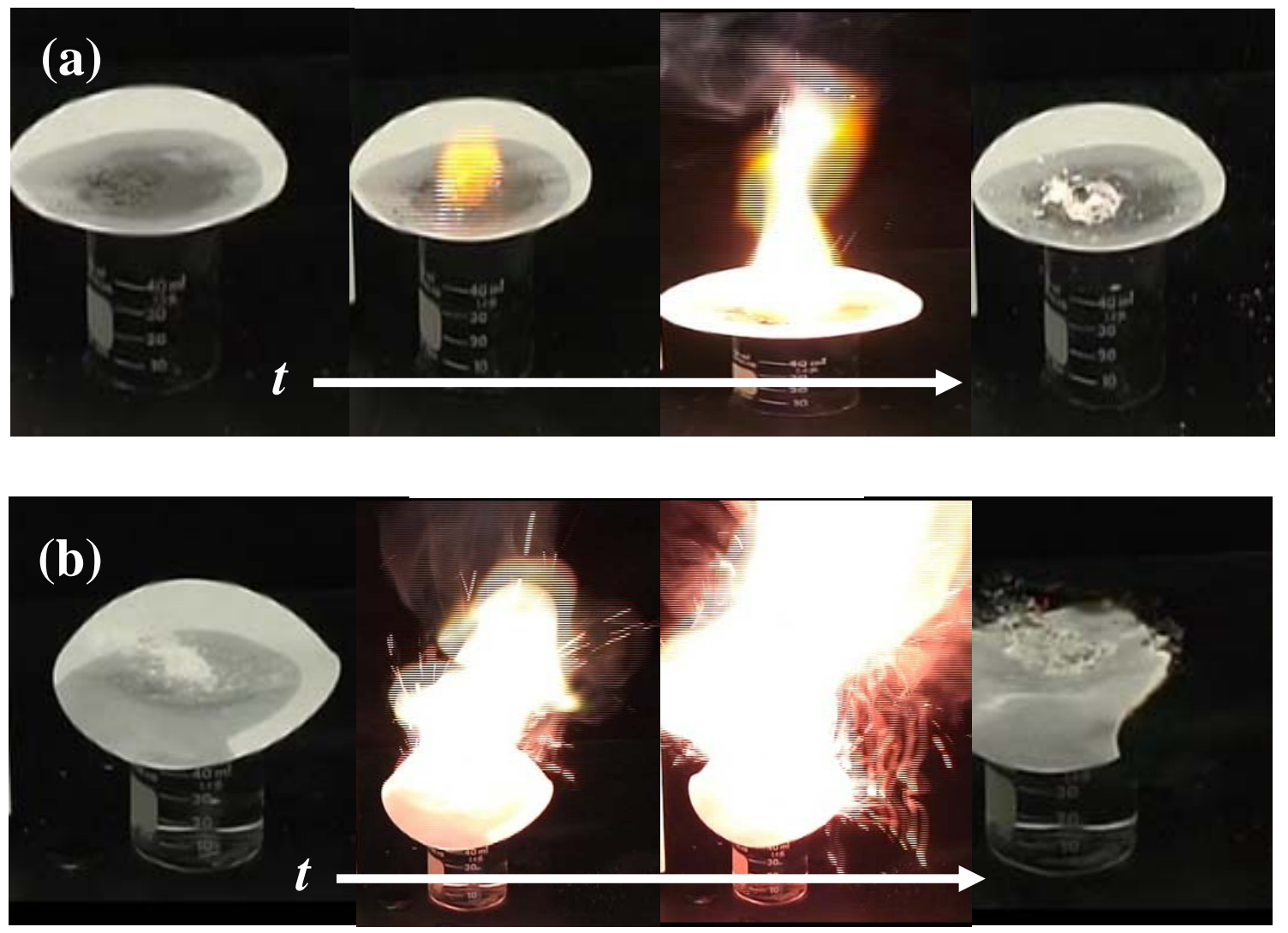

Figure 2 - Results of the Surface Contact Test for (a) $\mathrm{MgH}_{2}$ and (b) $\mathrm{LiBH}_{4}$ Showing NearInstantaneous Reaction. Time Increases from Left to Right. 
The final water reactivity test is the Water Drop test, wherein a few drops of water are added to a small conical pile of material. In this case, the hydride material is present in excess of the amount of water theoretically required to fully react via hydrolysis. It can be seen that $\mathrm{MgH}_{2}$, Figure 3a required several drops of water to react, with the first several drops forming small balls of material that rolled off to the side due to the hydrophobic nature. After several attempts, a ball rested on top of the conical pile and this orientation led to the observed reactivity. This material continued to burn for several minutes, after which an ashen pile remained. In comparison, the $\mathrm{LiBH}_{4}$, Figure 3b, material reacted nearly instantaneously in a much stronger event compared to the $\mathrm{MgH}_{2}$. The observed sparks are most likely caused by the burning of the lithium itself. 

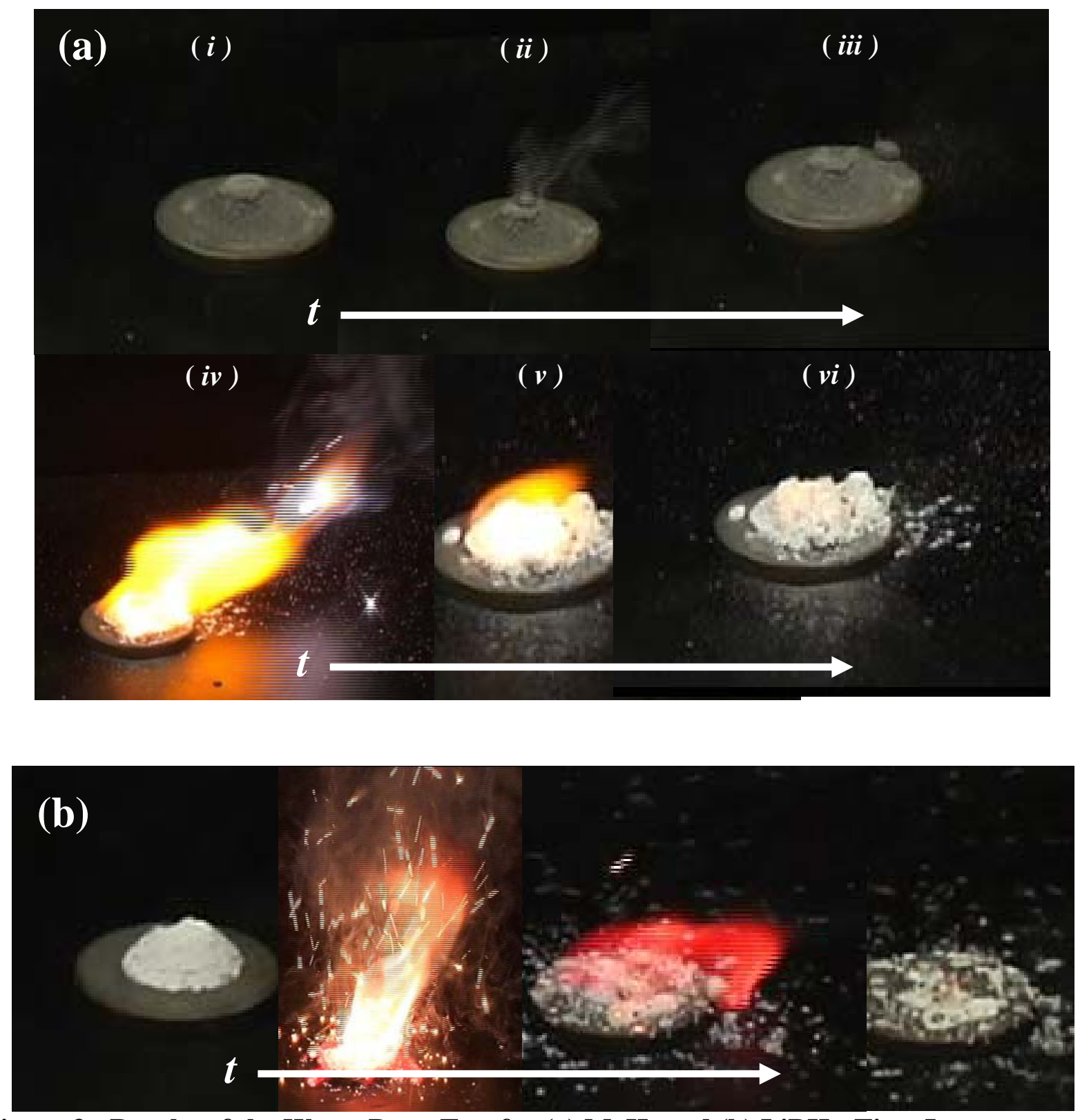

Figure 3 - Results of the Water Drop Test for (a) $\mathrm{MgH}_{2}$ and (b) $\mathrm{LiBH}_{4}$. Time Increases from Left to Right.

In the case of the fully charged, destabilized $2 \mathrm{LiBH}_{4} \cdot \mathrm{MgH}_{2}$ the same tests were performed. The results of water reactivity are shown in Figure 4. From Figure 4a, Water Immersion test, the material tends to form a film on the surface of the water, with very small spark-like events noted in some cases. At longer times, gas is evolved from the materials in the 
film. This is consistent with the expectations of $2 \mathrm{LiBH}_{4} \cdot \mathrm{MgH}_{2}$ because the reactivity fell between the reactivity behavior of the parent $\mathrm{MgH}_{2}$ and $\mathrm{LiBH}_{4}$. The film-like formation is similar to that observed in the $\mathrm{MgH}_{2}$, while the sparking and instantaneous reaction is similar to $\mathrm{LiBH}_{4}$. The results of the Surface Contact Test are shown in Figure $4 \mathrm{~b}$, where it can be seen that the material is immediately reactive with the water soaked filter paper. The bubble evolution prior to ignition is consistent with $\mathrm{MgH}_{2}$, while the actual reactive event was seen with both constituent materials. Finally, the Water Drop Test, Figure 4c, shows a material that is highly reactive with the addition of a few drops of water with respect to a relatively large amount of the hydride material. The mixture is instantly reactive, much like $\mathrm{LiBH}_{4}$ while the reaction takes several minutes to completely burn out, which is similar to $\mathrm{MgH}_{2}$. 

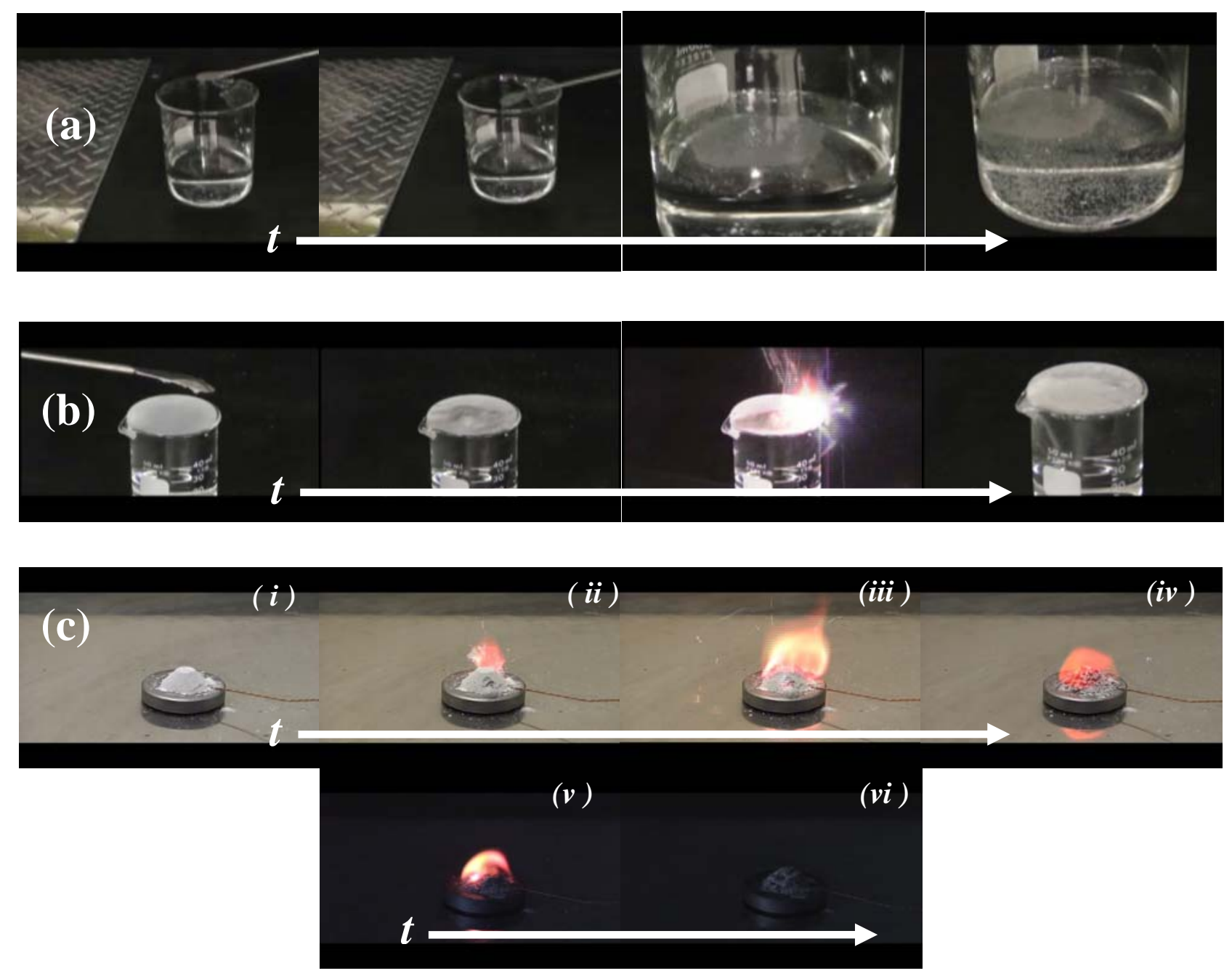

Figure 4 - Water reactivity results for (a) Water Immersion (b) Surface Contact, and (c) Water Drop Test for $2 \mathrm{LiBH}_{4} \cdot \mathrm{MgH}_{2}$. Time Increases from Left to Right.

In addition, the Water Drop test was slightly modified to record temperature data at a location underneath the pile. The maximum temperature reached was approximately $180{ }^{\circ} \mathrm{C}$ after 4 minutes at which time the temperature began to decrease. The temperature reached nearroom temperature just after 10 minutes. Based on these results it is clear that the $2 \mathrm{LiBH}_{4} \cdot \mathrm{MgH}_{2}$ is reactive with water, as are the more well-known constituent materials $\mathrm{LiBH}_{4}$ and $\mathrm{MgH}_{2}$.

The difference in the observed water reactivity of $2 \mathrm{LiBH}_{4} \cdot \mathrm{MgH}_{2}$ compared to the parent materials is the result of different heat dissipation rates in the three scenarios and the rate of 
hydrogen generation. In the Water Drop Test, hydrogen gas is rapidly evolved via the hydrolysis of the constituent $\mathrm{LiBH}_{4}$ and $\mathrm{MgH}_{2}$ materials; additionally, elemental $\mathrm{Mg}$ and Li may also be present in these samples after the ball milling process. These hydrolysis reactions are well known to be highly exothermic, and therefore the possibility of reaching the ignition temperature of the $\mathrm{H}_{2}$ is possible. In the Water Drop Test, there is no appreciable heat sink to reduce the temperature of the sample and surrounding air. Comparing this to the Water Immersion Test, hydrogen gas is clearly evolved via hydrolysis, as in the Water Drop Test. However, with the presence of the relatively large amount of water in intimate contact with the material, the heat is more quickly wicked away thus preventing a reactive event. The Surface Contact Test is a hybrid between the two scenarios, where the mass transport of the water to the hydride for reaction is impeded by the presence of the filter paper, as is the transfer of the heat to the water which is restricted to only the bottom surface of the pile through the filter. It is obvious that this material is sufficiently reactive to build up enough heat energy and $\mathrm{H}_{2}$ to give rise to an ignition event.

The $2 \mathrm{LiBH}_{4} \cdot \mathrm{MgH}_{2}$ was also tested using the procedure for the U.N. Pyrophoricity classification, Figure 5. Approximately $1 \mathrm{~g}$ of the material was dropped into a box with glass sides with the bottom made from industrial grade aluminum sheeting. The test nominally stipulates a 5 min waiting period. No reaction of the material in the air during the material drop, or within 15 minutes after the material was allowed to remain on the ground, was observed. Therefore, the material is deemed to be non-pyrophoric by the metrics used in this test. 


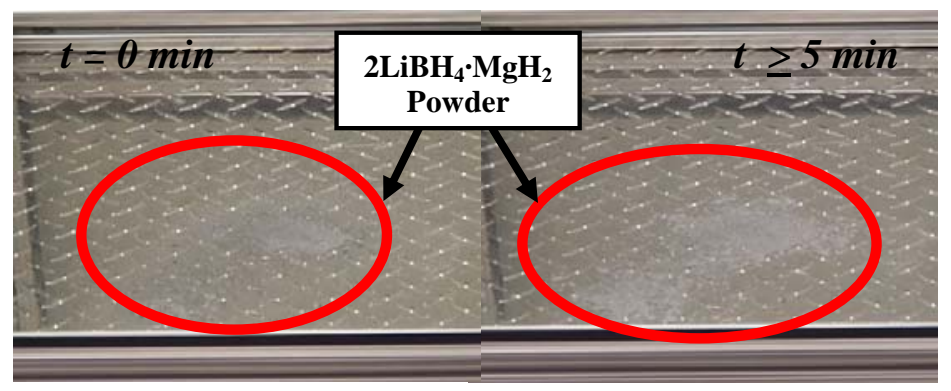

Figure 5 - Results from the Pyrophoricity Test for $2 \mathrm{LiBH}_{4} \cdot \mathrm{MgH}_{2}$.

The results of the Self-Heating Test for $2 \mathrm{LiBH}_{4} \cdot \mathrm{MgH}_{2}$ are shown below in Figure 6. Data were collected at 5 minute intervals during this experiment. A background control experiment was performed on a $\mathrm{SiO}_{2}$ sample which was loaded into the sample container and placed into the oven. The test was started at room temperature $(\mathrm{t}=0 \mathrm{~min})$; however, after 5 minutes the highest reading is experienced at the face-center location $\left(\mathrm{T}=\sim 400^{\circ} \mathrm{C}\right)$, with the $2^{\text {nd }}$ highest temperature at the corner $\left(\mathrm{T}=\sim 320^{\circ} \mathrm{C}\right)$, and the temperature at the center of the sample relatively low at $\mathrm{T}=\sim 240^{\circ} \mathrm{C}$ ). It should be noted that the criterion for failure of the self-heating test is for the sample to heat above the ambient temperature by $60^{\circ} \mathrm{C}$ or more; thus the sample has already experienced dangerous self-heating at this point in the experiment. After the passage of another 5 minutes, the temperature of the center is now the highest measurement $(\mathrm{T}=$ $\left.\sim 410^{\circ} \mathrm{C}\right)$, followed by the temperature of the corner $\left(\mathrm{T}=\sim 340^{\circ} \mathrm{C}\right)$, followed by the temperature of the face-center $\left(\mathrm{T}=\sim 290^{\circ} \mathrm{C}\right)$. As time proceeds, the center increases until a maximum reading of $\sim 450^{\circ} \mathrm{C}$, after which the sample cools until it reaches a steady state of approximately $150^{\circ} \mathrm{C}$, consistent with the background temperature from the $\mathrm{SiO}_{2}$ sample. These results are interpreted as the procession of a reaction front, which starts at the face-center thermocouple, then proceeds towards the slightly more interior corner thermocouple, and finally to the central thermocouple. The relative insulation surrounding the central couple, provided by the reacted material, causes the couple to retain more heat and reach higher temperatures. These results are consistent with 
temperature enhanced hydrolysis and oxidation of the hydride materials resulting from the contact with the ambient air in the oven at the elevated temperature of the test.

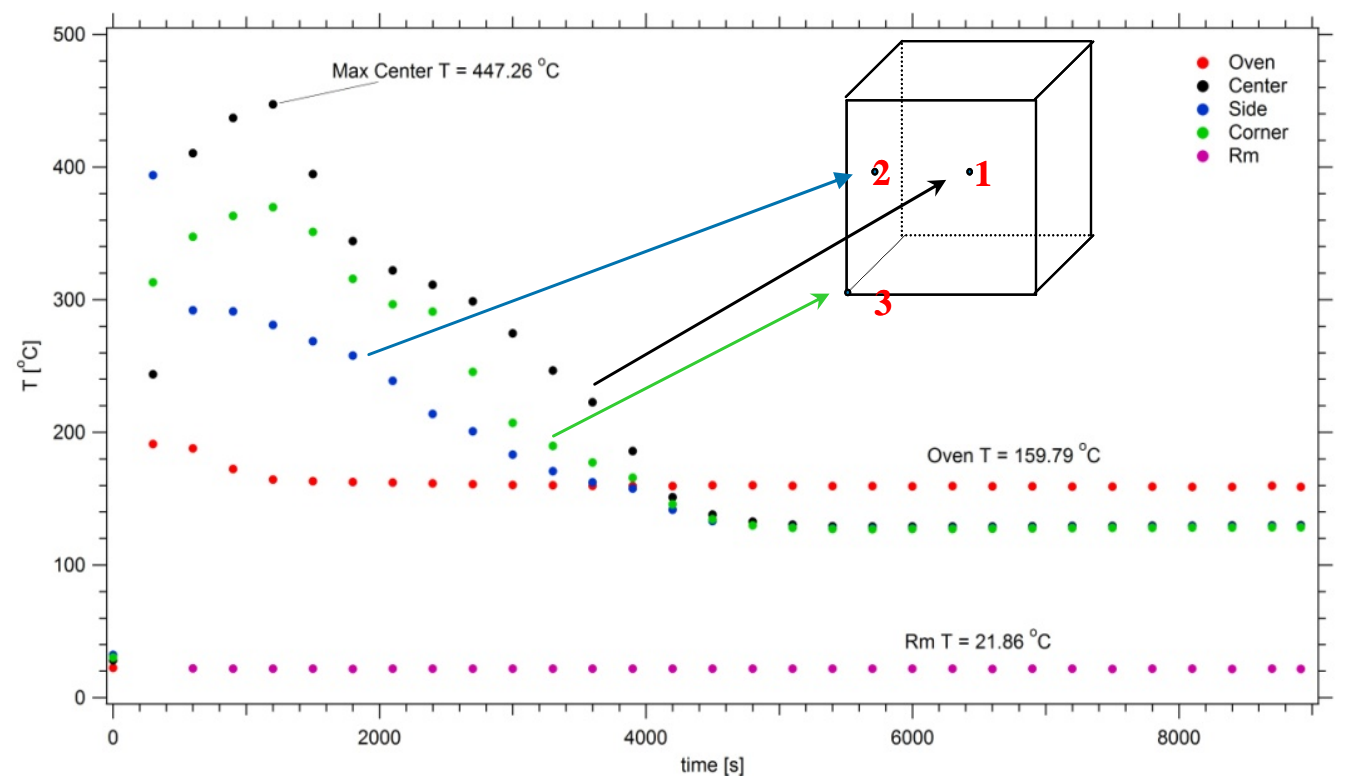

Figure 6 - Thermocouple readings for the Self-Heating Test performed on $2 \mathrm{LiBH}_{4} \cdot \mathrm{MgH}_{2}$. (Red $=$ Oven Temperature, Black $=$ Sample Center Temperature, Blue $=$ Sample Side Temperature, Green = Sample Corner Temperature)

Figure 7 shows the results of the Burn Rate Test for the $2 \mathrm{LiBH}_{4} \cdot \mathrm{MgH}_{2}$ material. In Figure $7 \mathrm{a}$, a photograph is shown which was taken $\sim 5 \mathrm{~s}$ into the burn rate test, after which time the flame had propagated the entire length of the sample. It is obvious that the material is combustible by the metrics employed in this test. In Figure $7 b$, the results of the thermocouple measurements are shown as a function of time. In the upper right of the figure is an inset showing a blown-up depiction of the initiation period from $750 \mathrm{~s}-800 \mathrm{~s}$. The burn rate reported uses an average of the time optically measured using the video recording data, and the time measured using the thermocouple results. The calculated burn rate for this experiment was 52 $\mathrm{mm} / \mathrm{s}$. This value is very similar to the value previously measured for $\mathrm{NaAlH}_{4}$ by Mosher et al of $51 \mathrm{~mm} / \mathrm{s}$. The lack of symmetry in the thermocouple measurements between the couples 
which are reflectively displaced from the midpoint of the sample length axis is attributed to spatial non-uniformity of the sample during the test.

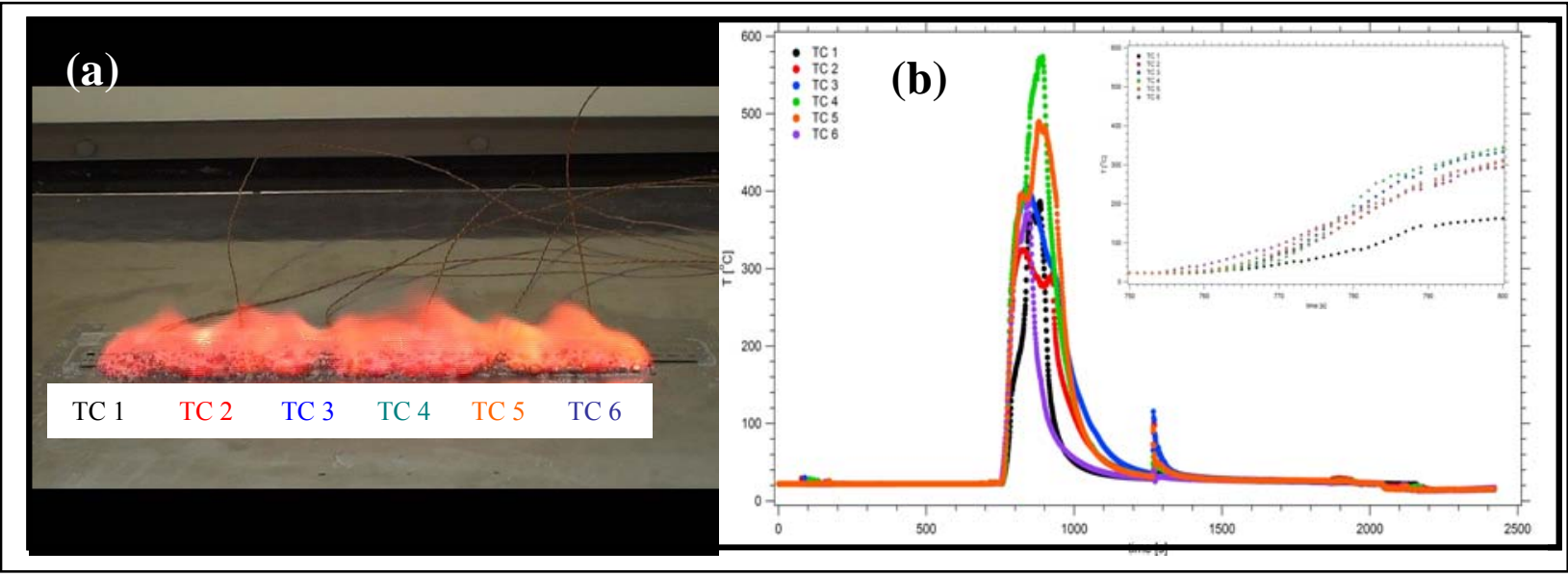

Figure 7 - Results of the Burn Rate Test for the $2 \mathrm{LiBH}_{4} \cdot \mathrm{MgH}_{2}$ material. a) Photograph of Burning Material after 5 seconds, b) Thermocouple Readings.

The findings of the current modified U.N. testing procedures for $2 \mathrm{LiBH}_{4} \cdot \mathrm{MgH}_{2}$ are summarized in Table 1, along with the results of the individual pure constituent materials.

Table 1: Results of the U.N. Standardized Tests for charged $2 \mathrm{LiBH}_{4} \cdot \mathrm{MgH}_{2}$

\begin{tabular}{|c|c|c|c|c|c|c|}
\hline \begin{tabular}{|c} 
Material / UN \\
Test
\end{tabular} & Pyrophoricity & Self-Heat & Burn Rate & $\begin{array}{l}\text { Water } \\
\text { Drop }\end{array}$ & $\begin{array}{l}\text { Surface } \\
\text { Contact }\end{array}$ & $\begin{array}{c}\text { Water } \\
\text { Immersion }\end{array}$ \\
\hline $\mathrm{MgH}_{2}$ & Not Tested & Not Tested & Not Tested & $\begin{array}{c}2 \mathrm{H}_{2} \mathrm{O} \text { drops } \\
\text { required for } \\
\text { near-instant } \\
\text { ignition. }\end{array}$ & $\begin{array}{c}\text { Material } \\
\text { ignited }\end{array}$ & \begin{tabular}{|c} 
No ignition \\
event recorded. \\
Gas evolved at \\
longer times. \\
$(5 \mathrm{~min})$
\end{tabular} \\
\hline $\mathrm{LiBH}_{4}$ & Not Tested & Not Tested & Not Tested & $\begin{array}{c}2 \mathrm{H}_{2} \mathrm{O} \text { drops } \\
\text { required for } \\
\text { near-instant } \\
\text { ignition. }\end{array}$ & $\begin{array}{l}\text { Material } \\
\text { ignited }\end{array}$ & $\begin{array}{l}\text { No ignition } \\
\text { event recorded. } \\
\text { Gas evolved at } \\
\text { longer times. } \\
(5 \mathrm{~min})\end{array}$ \\
\hline $2 \mathrm{LiBH}_{4} \cdot \mathrm{MgH}_{2}$ & $\begin{array}{c}\text { No ignition } \\
\text { event. } \\
\text { Hygroscopic } \\
\text { material } \\
\text { absorbed } \mathrm{H}_{2} \mathrm{O} \\
\text { from air. } \\
\end{array}$ & $\begin{array}{c}\text { Self-heated } \\
\sim 300^{\circ} \mathrm{C} \text { within } \\
5 \text { min at as } \\
\mathrm{T}_{\text {oven }}=150^{\circ} \mathrm{C} \\
\text { is approached. }\end{array}$ & $\begin{array}{c}\text { Flame } \\
\text { propagated in } \\
5 \mathrm{sec} \text { with burn } \\
\begin{array}{c}\text { rate of } 52 \\
\mathrm{~mm} / \mathrm{sec} .\end{array}\end{array}$ & $\begin{array}{c}2 \mathrm{H}_{2} \mathrm{O} \text { drops } \\
\text { required for } \\
\text { near-instant } \\
\text { ignition. }\end{array}$ & $\begin{array}{c}\text { Material } \\
\text { ignited }\end{array}$ & $\begin{array}{l}\text { No ignition } \\
\text { event recorded. } \\
\text { Gas evolved at } \\
\text { longer times. } \\
\quad(5 \mathrm{~min})\end{array}$ \\
\hline
\end{tabular}


3.2 Calorimetry

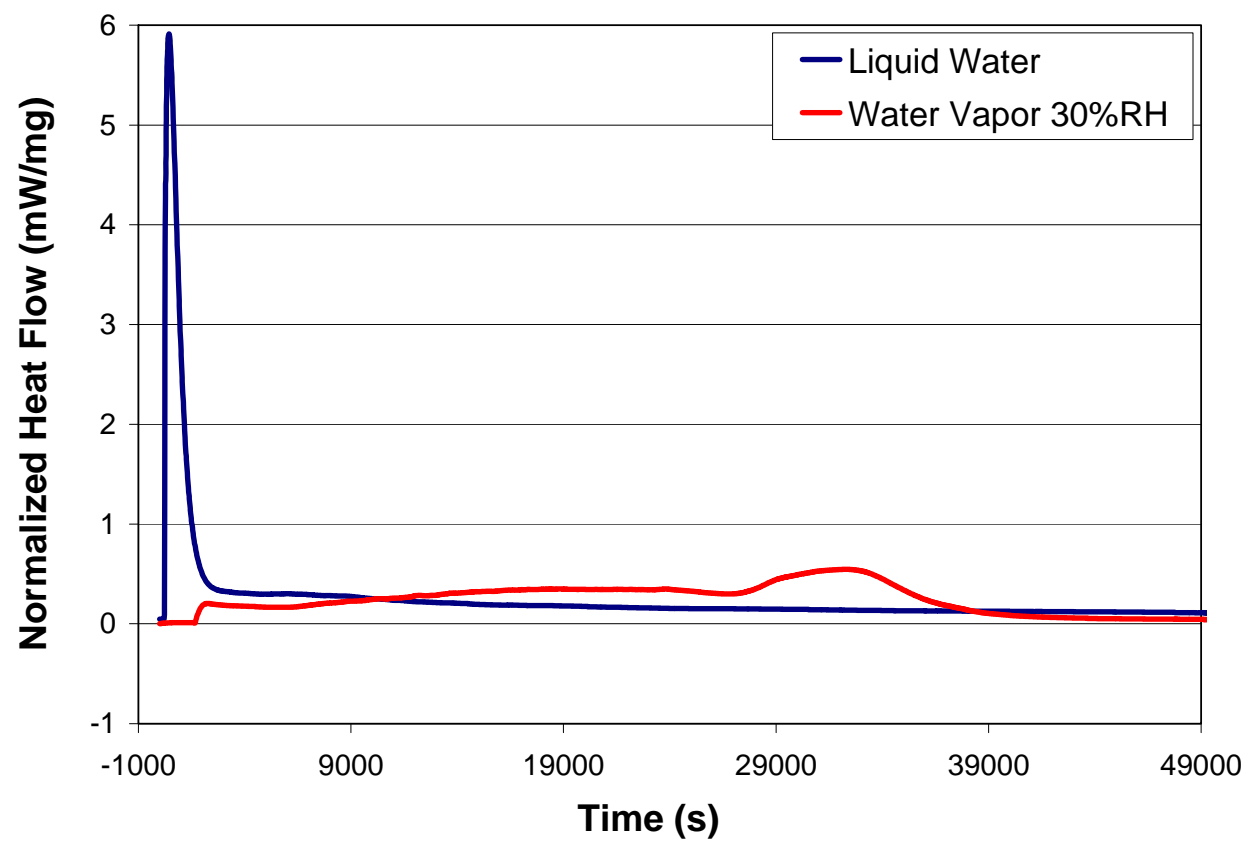

Figure 8 - Normalized heat flow (mW/mg) during hydrolysis/oxidation of $2 \mathrm{LiBH}_{4} \cdot \mathrm{MgH}_{2}$ with liquid water at $40^{\circ} \mathrm{C}$ and with $30 \%$ relative humidity air at $40^{\circ} \mathrm{C}(10 \mathrm{ml} / \mathrm{min}$ flow rate).

Figure 8 displays the normalized heat flow $\left(\mathrm{mW} / \mathrm{mg}\right.$ ) for the $2 \mathrm{LiBH}_{4} \cdot \mathrm{MgH}_{2}$ reaction with liquid water in a mixing cell compared with water vapor in a gas flow cell. From Figure 1a it is seen that the amount of water addition in excess of stoichiometry is 32 times for liquid water and 4 times greater after a reaction time of 12 hours for the conditions of $40^{\circ} \mathrm{C}$ and $30 \%$ relative humidity. The qualitative difference observed in heat flow is believed to be due to the difference in gas/solid versus liquid/solid interfacial reactions. The total energy released through the water vapor reaction was greater $(-268 \mathrm{~kJ} / \mathrm{mol})$ than the energy release upon liquid water hydrolysis ($223 \mathrm{~kJ} / \mathrm{mol}$ ). In addition the final crystalline reaction products were different in the two cases: the reaction with $30 \%$ relative humidity air resulted in $\mathrm{LiB}(\mathrm{OH})_{4}$ and residual $\mathrm{MgH}_{2}$, while the liquid water hydrolysis resulted in $\mathrm{LiB}(\mathrm{OH})_{4}, \mathrm{H}_{6} \mathrm{~B}_{2} \mathrm{O}_{6}$ and $\mathrm{LiB}(\mathrm{OH})_{2}\left(\mathrm{O}_{2}\right)$. . 
Table 2 summarizes the liquid mixing and gas flow reaction experiments performed both on the pure component $\mathrm{LiBH}_{4}$ and $\mathrm{MgH}_{2}$ as well as the destabilized mix $\left(2 \mathrm{LiBH}_{4} \cdot \mathrm{MgH}_{2}\right)$ materials. Overall, in both the liquid mixing and gas flow reactions the trend is for a lower measured energy compared to the thermodynamically predicted reactions. A corollary to this is that the actual observed products do not match those predicted from thermodynamics and often have a significant degree of amorphous character.

An apparent anomaly in Table 2 for the reaction of liquid water with $\mathrm{LiBH}_{4}$ is the actual measured $\Delta \mathrm{H}(-320 \mathrm{~kJ} / \mathrm{mol})$ which is greater than the reaction for the theoretical lowest energy product predicted from the thermodynamic database. However the $\Delta \mathrm{H}$ for the theoretical product does not take into consideration the heat of dissolution in aqueous solution of $\mathrm{LiBH}_{4} \rightarrow$ $\mathrm{Li}^{+}+\mathrm{BH}_{4}{ }^{-}$with an enthalpy of $\sim 43 \mathrm{~kJ} / \mathrm{mol}$ at $40^{\circ} \mathrm{C}$. In addition, the actual products were found to be amorphous lithium plus boron hydroxide product indicating a different reaction pathway occurred than thermodynamically predicted. The hydrolysis and oxidation of magnesium hydride was found to be extremely slow with starting material found in the final product and total measured heat of reaction less than $1 \%$ of those experimentally predicted. This is believed to be due to the relatively high stability of the $\mathrm{Mg}(\mathrm{OH})_{2}$ surface layer $(\Delta \mathrm{H}$ formation -334 $\mathrm{kJ} / \mathrm{mol})$. 
Table 2: Experimental versus Theoretical Products and Reaction Energies

\begin{tabular}{|c|c|c|c|}
\hline Material System & $\begin{array}{l}\text { Environmental } \\
\text { Exposure }\end{array}$ & $\begin{array}{c}\text { Theoretical } \\
\text { Product } \\
\Delta \mathrm{H}(\mathrm{kJ} / \mathrm{mole}) \text { at } \\
40^{\circ} \mathrm{C}\end{array}$ & $\begin{array}{c}\text { Actual Product } \\
\Delta \mathrm{H}(\mathrm{kJ} / \mathrm{mole}) \text { at } 40^{\circ} \mathrm{C}\end{array}$ \\
\hline \multirow{3}{*}{$\mathrm{LiBH}_{4}$} & $\mathrm{H}_{2} \mathrm{O}$ (liquid) & $\begin{array}{c}\mathrm{LiBO}_{2} \\
-258\end{array}$ & $\begin{array}{c}\text { Amorphous } \mathrm{Li}+\mathrm{B}(\mathrm{OH})_{3} \\
-320\end{array}$ \\
\hline & $\begin{array}{c}\mathrm{H}_{2} \mathrm{O}(\text { gas })+ \\
\mathbf{O}_{2} \text { air }\end{array}$ & $\begin{array}{c}\mathrm{LiOH}+\mathrm{H}_{3} \mathrm{BO}_{2} \\
-1386\end{array}$ & $\begin{array}{c}\mathrm{LiB}(\mathrm{OH})_{4}+\mathrm{H}_{6} \mathrm{~B}_{2} \mathrm{O}_{6}+ \\
\mathrm{LiB}(\mathrm{OH})_{2}\left(\mathrm{O}_{2}\right) \\
-352\end{array}$ \\
\hline & $\begin{array}{c}\mathrm{H}_{2} \mathrm{O}(\text { gas })+ \\
\text { Argon }\end{array}$ & $\begin{array}{l}\mathrm{LiBO}_{2} \\
-344\end{array}$ & $\begin{array}{c}\mathrm{LiB}(\mathrm{OH})_{4} \\
-340\end{array}$ \\
\hline \multirow[t]{2}{*}{$\mathrm{MgH}_{2}$} & $\mathrm{H}_{2} \mathrm{O}$ (liquid) & $\begin{array}{l}\mathrm{Mg}(\mathrm{OH})_{2} \\
-278\end{array}$ & $\begin{array}{c}\mathrm{Mg}(\mathrm{OH})_{2}+\mathrm{Mg}+\mathrm{MgH}_{2} \\
<-1\end{array}$ \\
\hline & $\begin{array}{c}\mathrm{H}_{2} \mathrm{O}(\text { gas })+ \\
\mathbf{O}_{2} \text { air }\end{array}$ & $\begin{array}{l}\mathrm{Mg}(\mathrm{OH})_{2} \\
-848\end{array}$ & $\begin{array}{c}\mathrm{Mg}+\mathrm{MgH}_{2} \\
<-1\end{array}$ \\
\hline \multirow{2}{*}{$\begin{array}{l}\text { Fully Charged } \\
2 \mathrm{LiBH}_{4} \cdot \mathrm{MgH}_{2}\end{array}$} & $\mathrm{H}_{2} \mathrm{O}$ (liquid) & $\begin{array}{c}\mathrm{LiOH}+1 / 2 \\
\mathrm{Mg}(\mathrm{OH})_{2} \\
+\mathrm{H}_{3} \mathrm{BO}_{2} \\
-445\end{array}$ & $\begin{array}{c}\text { Amorphous } \mathrm{Li}+\mathrm{LiB}(\mathrm{OH})_{4}+ \\
\mathrm{Mg}(\mathrm{OH})_{2}+\text { Lithium borate hydrates } \\
-223\end{array}$ \\
\hline & $\begin{array}{c}\mathrm{H}_{2} \mathrm{O}(\text { gas })+ \\
\mathbf{O}_{2} \text { air }\end{array}$ & $\begin{array}{l}\mathrm{LiOH}+1 / 2 \\
\mathrm{Mg}(\mathrm{OH})_{2} \\
+\mathrm{H}_{3} \mathrm{BO}_{2} \\
-1206\end{array}$ & $\begin{array}{l}\mathrm{LiB}(\mathrm{OH})_{4}+\mathrm{MgH}_{2} \\
-268\end{array}$ \\
\hline \multirow[t]{2}{*}{$\begin{array}{l}\text { Fully Discharged } \\
2 \mathrm{LiH} \cdot \mathrm{MgB}_{2}\end{array}$} & $\mathrm{H}_{2} \mathrm{O}$ (liquid) & $\begin{array}{c}\mathrm{LiOH}+ \\
\mathrm{Mg}(\mathrm{OH})_{2}+ \\
\mathrm{H}_{3} \mathrm{BO}_{2} \\
-761\end{array}$ & $\begin{array}{c}\text { Amorphous } \mathrm{Li}+\mathrm{Mg}(\mathrm{OH})_{2} \\
\mathrm{Mg}_{5}\left(\mathrm{BO}_{3}\right) \mathrm{O}(\mathrm{OH})_{5} \cdot 2 \mathrm{H}_{2} \mathrm{O}+ \\
\mathrm{MgB}_{12} \mathrm{O}_{19}\left(\mathrm{H}_{2} \mathrm{O}\right)_{5} \\
-170\end{array}$ \\
\hline & $\begin{array}{c}\mathrm{H}_{2} \mathrm{O}(\text { gas })+ \\
\mathbf{O}_{2} \text { air }\end{array}$ & $\begin{array}{c}\mathrm{LiOH}+\mathrm{MgO}+ \\
\mathrm{B}_{2} \mathrm{O}_{3} \\
-1289\end{array}$ & $\begin{array}{c}\mathrm{Mg}(\mathrm{OH})_{2}+\mathrm{LiB}(\mathrm{OH})_{4}+\mathrm{LiOH} \cdot \mathrm{H}_{2} \mathrm{O} \\
-205\end{array}$ \\
\hline
\end{tabular}

When humid air is used as the reactive gas, there are two competing reactions; that between the material and oxygen and between the material and water vapor in addition to the possibility of hydrogen oxidation in the presence of air. Consideration of these effects independently using thermodynamic database revealed that the air oxidation was the predicted 
dominant reaction. As a way to experimentally verify the effect of oxidation versus gas phase hydrolysis, argon as a carrier gas with $30 \%$ relative humidity was used in the $\mathrm{LiBH}_{4}$ material system as a control experiment. With humid air as the gas reactant, the predicted energy release of $-1386 \mathrm{~kJ} / \mathrm{mol}$ comes from oxidation, while use of the humid argon reactive gas predicts an energy release of $-344 \mathrm{~kJ} / \mathrm{mol}$ from gas phase hydrolysis. XRD analysis showed the major product to be the same from the two reactions, $\mathrm{LiB}(\mathrm{OH})_{4}$. However the reaction that occurred in the presence of air had small amounts of $\mathrm{H}_{6} \mathrm{~B}_{2} \mathrm{O}_{6}$ as well as $\mathrm{LiB}(\mathrm{OH})_{4}\left(\mathrm{O}_{2}\right)$, but exhibited only a slight increase in the total amount of energy released. Insufficient data on the heats of formation are available to perform a thermodynamic analysis of these reactions.

The results of maximum heat flow during environmental exposure scenarios are presented in Figure 9 for both mixing with liquid water and in humid air and argon gas flow experiments. The data indicate that it is not the oxidative effects of oxygen which are of greatest risk for promoting energy release in the $2 \mathrm{LiBH}_{4} \cdot \mathrm{MgH}_{2}$ system, but it is the presence of gaseous oxygen itself which can combine with the hydrogen released from hydrolysis that is the real danger in environmental exposure scenarios. 


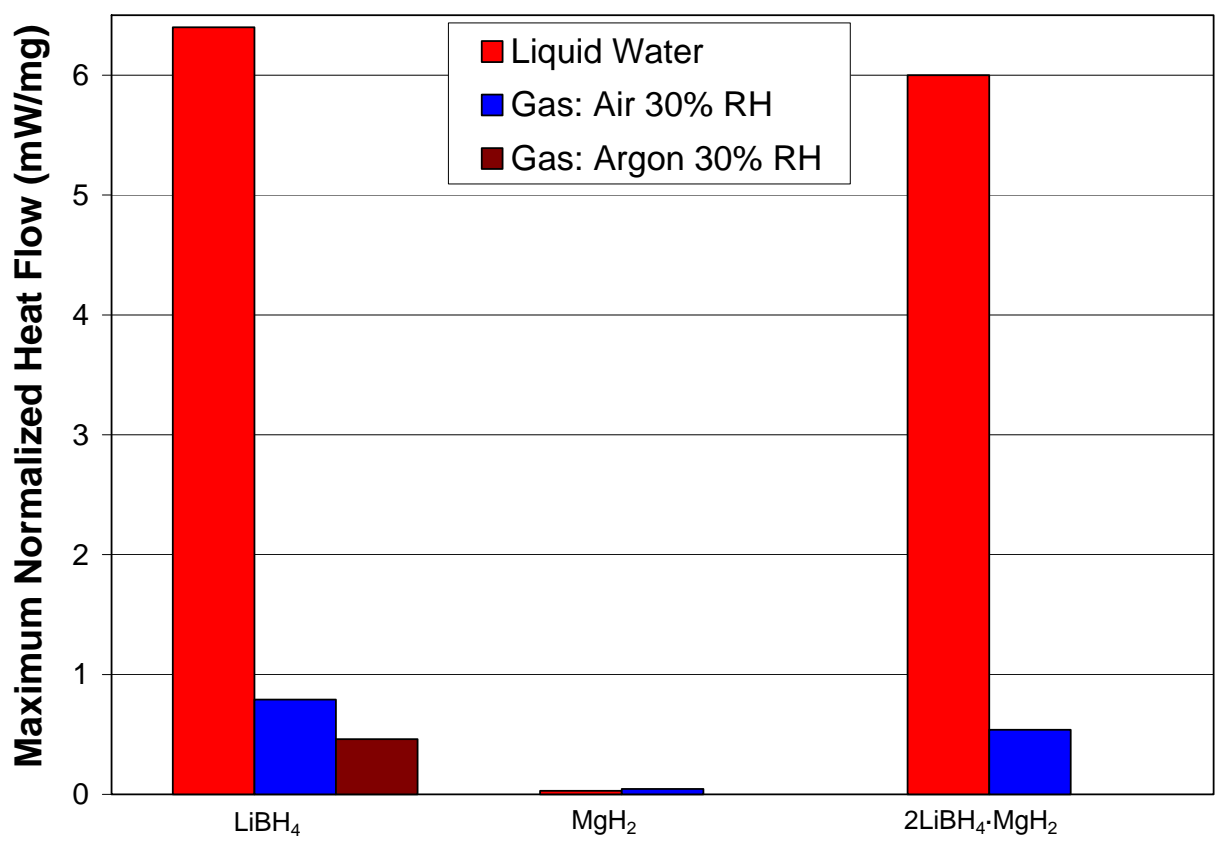

Figure 9 - Maximum rate of heat flow during hydrolysis at $40^{\circ} \mathrm{C}$ with liquid water, gas flow air with $30 \%$ relative humidity, and gas flow argon with $30 \%$ relative humidity.

\section{Materials Charged State}

Figure 10 presents the maximum heat flow for liquid phase hydrolysis at $40^{\circ} \mathrm{C}$ and $70^{\circ} \mathrm{C}$ as a function of the materials hydrogen charged state. The maximum heat flow increases as the material desorbs hydrogen and converts into more reactive $\mathrm{LiH}, \mathrm{Mg}$, and $\mathrm{MgB}_{2}$ chemical compounds as predicted by the following chemical reactions:

$$
\begin{aligned}
& \mathrm{LiBH}_{4}+1 / 2 \mathrm{MgH}_{2}+4 \mathrm{H}_{2} \mathrm{O}(\mathrm{l})=\mathrm{LiOH}+1 / 2 \mathrm{Mg}(\mathrm{OH})_{2}+\mathrm{H}_{3} \mathrm{BO}_{2}+4 \mathrm{H}_{2}(\mathrm{~g}) \quad \Delta \mathrm{H}=-675 \mathrm{~kJ} / \text { formula unit } \\
& \mathrm{LiH}+1 / 2 \mathrm{MgB}_{2}+4 \mathrm{H}_{2} \mathrm{O}(\mathrm{l})=\mathrm{LiOH}+1 / 2 \mathrm{Mg}(\mathrm{OH})_{2}+\mathrm{H}_{3} \mathrm{BO}_{2}+2 \mathrm{H}_{2}(\mathrm{~g}) \quad \Delta \mathrm{H}=-760 \mathrm{~kJ} / \text { formula unit }
\end{aligned}
$$

Equations 2 and 3 represent the total amount of heat release expected for these reactions, while Figure 10 presents the rate of energy release, or maximum heat flux per mass of material $(\mathrm{mW} / \mathrm{mg})$. This data brings us to the important conclusion that the discharged material states are 
more reactive to air and water exposure than the fully charged material states in the $2 \mathrm{LiBH}_{4} \cdot \mathrm{MgH}_{2}$ system. Risk assessments made in engineering design for storage tanks containing the $2 \mathrm{LiBH}_{4} \cdot \mathrm{MgH}_{2}$ material should take into account the discharged material states as a possible worst case estimate for environmental exposure scenarios.

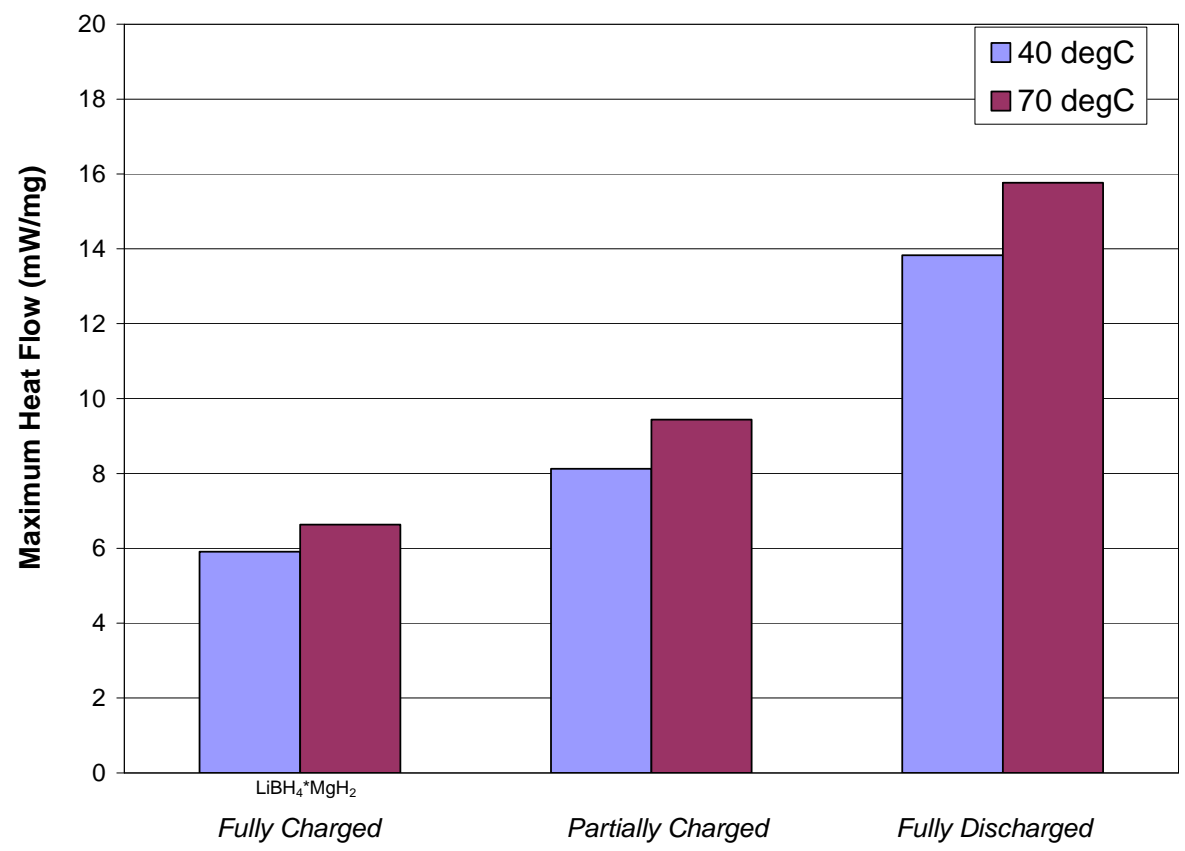

Figure 10 - Maximum heat flow (mW/mg) under liquid hydrolysis conditions as a function of temperature for fully charged, partially charged and fully discharged $2 \mathrm{LiBH}_{4} \cdot \mathrm{MgH}_{2}$

\subsection{Heat/Mass Transfer in correlation b/w UN tests and Calorimetry: Predicting risk}

The ultimate goal of the studies investigating the safety of hydrogen storage materials is to combine the physical property and reactivity data for the materials with modeling based on nondimensional parameters and heat/mass transfer to predict hydrogen ignition, time to hydrogen ignition and probability that the hydrogen ignition will then pyrolyze and burn the remaining storage material. The first step in this direction is comparing the calorimetric data on liquid water mixing and humid air reactivity to the relevant $\mathrm{UN}$ tests. The time to ignition due to heat release, hydrogen release and oxygen present in the atmosphere may be estimated assuming the 
thermal energy from the reaction is retained locally. For example, consider the time to ignition occurs when the energy release reaches $4.5 \times 10^{5} \mathrm{~J} / \mathrm{kg}$ assuming this energy goes into raising the temperature of the material to the auto-ignition temperature of hydrogen $\left(571^{\circ} \mathrm{C}\right)$. The experimental value for the total energy release is determined by integrating the area under the heat flow curve as a function of time resulting in a curve of total energy release versus time. The time where this curve reaches $4.5 \times 10^{5} \mathrm{~J} / \mathrm{kg}$ is the predicted time to ignition.

\section{Liquid Water Contact}

The experimental data for liquid water contact by calorimetry was based on an excess of water added at some initial time $\mathrm{t}=0$. The $\mathrm{UN}$ surface contact test most closely resembles this scenario where at $\mathrm{t}=0$, the material is added to a wet filter paper saturated with water provides excess water for the hydrolysis reaction. The integrated calorimetric data is presented in Figure 11a where the estimated energy was reached after approximately 40 seconds. Figure $11 \mathrm{~b}$ displays the hydrogen ignition event observed in the UN tests which occurred after approximately 10 seconds.

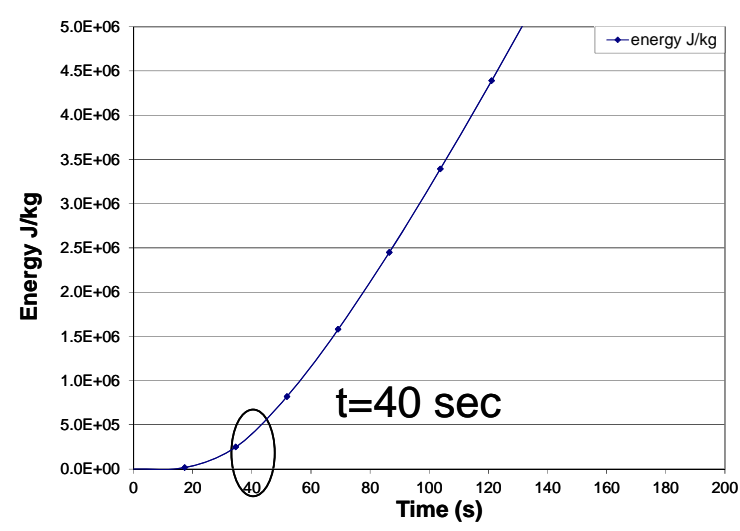

a)

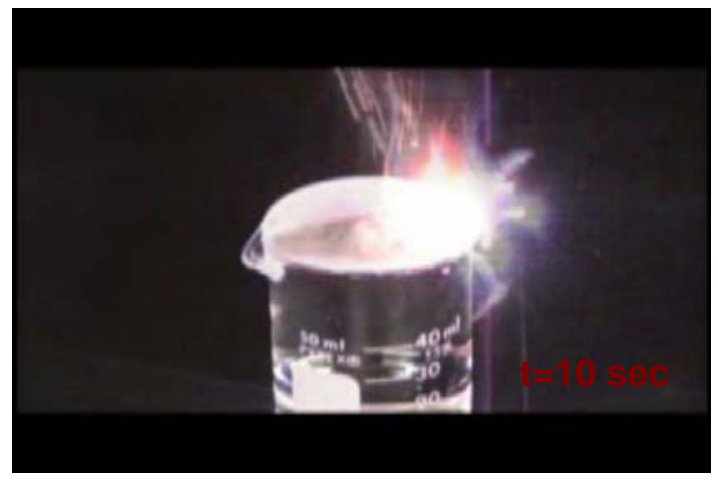

b)

Figure 11 - a) Total energy release ( $\mathrm{J} / \mathrm{g})$ determined by calorimetry as a function of time for liquid water hydrolysis at $40^{\circ} \mathrm{C}$ of $2 \mathrm{LiBH}_{4} \cdot \mathrm{MgH}_{2}$ b) Surface Contact test with $2 \mathrm{LiBH}_{4} \cdot \mathrm{MgH}_{2}$ displaying a flame event after 10 seconds 


\section{Water Vapor Contact}

The experimental data for water vapor contact by calorimetry was based on the amount of water vapor available for the hydrolysis reaction increasing as a function of time. The UN test which most closely resembles this was the pyrophoricity test where the material was dropped on the floor and exposed to ambient conditions in a fume hood with air circulation providing a flow rate of humid air across the material surface. The integrated calorimetric data is presented in Figure $12 \mathrm{a}$ where the estimated energy for ignition was not reached until over 1 hour of reaction. Figure $12 \mathrm{~b}$ displays the image of the material after 15 minutes of air exposure stipulated in the UN test showing no indication of any flame event. Obviously at the long ignition time predicted, the assumption of adiabatic conditions is not valid. Due to the long exposure times and inevitable heat dissipation, the material cannot reach the auto-ignition temperature of $\mathrm{H}_{2}\left(571{ }^{\circ} \mathrm{C}\right)$ and no flame event was observed

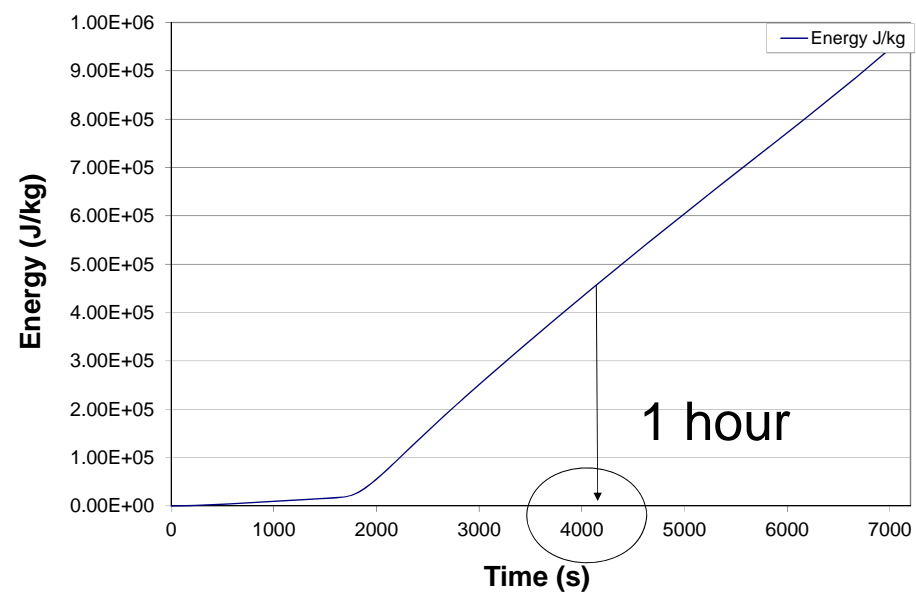

a)

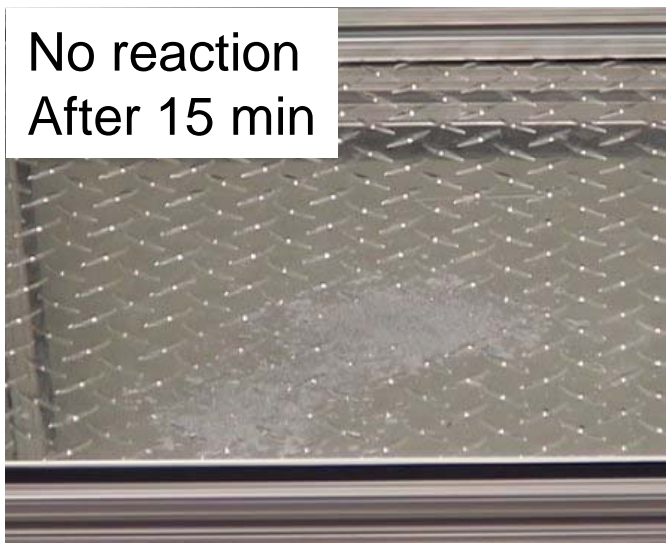

b)

Figure 12 - a)Total energy release ( $\mathrm{J} / \mathrm{g})$ determined by calorimetry as a function of time for water vapor hydrolysis at $40^{\circ} \mathrm{C}$ and $30 \%$ relative humidity of $2 \mathrm{LiBH}_{4} \cdot \mathrm{MgH}_{2}$ b) Pyrophoricity test of $2 \mathrm{LiBH}_{4} \cdot \mathrm{MgH}_{2}$ displaying no flame event after 15 minutes. 


\section{Conclusions}

The material $2 \mathrm{LiBH}_{4} \cdot \mathrm{MgH}_{2}$ has been evaluated using modified versions of United Nations test methodologies for shipping and packing classification. It was found that $2 \mathrm{LiBH}_{4} \cdot \mathrm{MgH}_{2}$ is reactive with both air and water under the conditions used in the current tests. The environmental reactivity of the destabilized $2 \mathrm{LiBH}_{4} \cdot \mathrm{MgH}_{2}$ system was most sensitive to water hydrolysis reactions with the destabilized mix following the behavior of the pure $\mathrm{LiBH}_{4}$ component due to the relative lack of $\mathrm{MgH}_{2}$ hydrolysis reactivity. A comparison of calorimetric data with relevant UN tests were used to develop the criteria for whether a given material will ignite based on the maximum heat flow and total energy released at times short enough to assume limited heat loss from the reaction system. The maximum normalized heat flow for the fully charged material was $6 \mathrm{~mW} / \mathrm{mg}$ under liquid phase hydrolysis; and $14 \mathrm{~mW} / \mathrm{mg}$ for the fully discharged material also occurring under liquid phase hydrolysis conditions. The experimentally observed products often contained significant amorphous content which are not reflected in the thermodynamic predictions. Finally, the dehydrogenated products were identified as having a higher potential heat release than the hydrogenated materials upon exposure to the environment, thus posing another risk factor in engineering hydrogen storage systems utilizing these materials.

\section{Acknowledgements}

The authors would like to thank David Missimer and Joseph Wheeler for their XRD and laboratory support, respectively. This work was funded under the U.S. Department of Energy Hydrogen Storage Program managed by Dr. Ned Stetson with whom many helpful and insightful discussions were held. 


\section{References}

[1] Anton DL. Hydrogen desorption kinetics in transition metal modified NaAlH4. Journal of Alloys and Compounds 2003;356-357:400.

[2] Walters RT, Scogin JH. A reversible hydrogen storage mechanism for sodium alanate: the role of alanes and the catalytic effect of the dopant. Journal of Alloys and Compounds 2004;379:135.

[3] Bogdanovic B, Felderhoff M, Germann M, Härtel M, Pommerin A, Schüth F, Weidenthaler $\mathrm{C}$, Zibrowius B. Investigation of hydrogen discharging and recharging processes of Tidoped NaAlH4 by X-ray diffraction analysis (XRD) and solid-state NMR spectroscopy. Journal of Alloys and Compounds 2003;350:246.

[4] Züttel A, Wenger P, Rentsch S, Sudan P, Mauron P, Emmenegger C. LiBH4 a new hydrogen storage material. J Power Sources 2003;118:1.

[5] Züttel A, Rentsch S, Fischer P, Wenger P, Sudan P, Mauron P, Emmenegger C. Hydrogen storage properties of LiBH4. Journal of Alloys and Compounds 2003;356-357:515.

[6] Au M. Hydrogen Storage Reversibility of LiBH4 Based Materials. Presentation at the Fall 2005 MRS Meeting, Boston, MA, 2005.

[7] Pinkerton FE. Decomposition kinetics of lithium amide for hydrogen storage materials. Journal of Alloys and Compounds 2005;400:76.

[8] Song Y, Yang R. Decomposition mechanism of magnesium amide $\mathrm{Mg}(\mathrm{NH} 2) 2$. Int $\mathrm{J}$ Hydrogen Energy 2009;34:3778.

[9] Lu J, Choi YJ, Fang ZZ, Sohn HY. Effect of milling intensity on the formation of LiMgN from the dehydrogenation of LiNH2-MgH2 (1:1) mixture. J Power Sources; 195:1992.

[10] Fisher M. Safety Aspects of Hydrogen Combustion in Hydrogen Energy-Systems. Int J Hydrogen Energy 1986;11:593.

[11] Mosher DA, Arsenault S, Tang X, Anton DL. Design, fabrication and testing of NaAlH4 based hydrogen storage systems. Journal of Alloys and Compounds 2007;446-447:707.

[12] Tanaka H, Tokoyoda K, Matsumoto M, Suzuki Y, Kiyobayashi T, Kuriyama N. Hazard assessment of complex hydrides as hydrogen storage materials. Int J Hydrogen Energy 2009;34:3210.

[13] Lohstroh W, Fichtner M, Breitung W. Complex hydrides as solid storage materials: First safety tests. Int J Hydrogen Energy 2009;34:5981.

[14] Vajo JJ, Skeith SL, Mertens F. Reversible Storage of Hydrogen in Destabilized LiBH4. J. Phys. Chem. B 2005;109:3719.

[15] Satyapal S, Petrovic J, Read C, Thomas G, Ordaz G. The U.S. Department of Energy's National Hydrogen Storage Project: Progress towards meeting hydrogen-powered vehicle requirements. Catalysis Today 2007;120:246.

[16] Fisher M. Safety Aspects in Hydrogen Energy Systems. Hydrogen Syst. Pap. Int. Symp. 1986;2:491.

[17] Hord J. How safe is hydrogen? Hydrogen Energy Distrib., Symp. Pap 1979:613.

[18] Green MA. Hydrogen Safety Issues Compared to Safety Issues with Methane and Propane. AIP Conference Proceedings, vol. 823, 2006. p.319.

[19] Ren R, Ortiz AL, Markmaitree T, Osborn W, Shaw LL. Stability of Lithium Hydride in Argon and Air. The Journal of Physical Chemistry B 2006;110:10567.

[20] Dedrick D, Behrens R, Bradshaw R. The Reactivity of Sodium Alanates with O2, H2O, and CO2. Sandia National Laboratory 2007;SAND2007-4960. 
[21] United Nations Recommendations on the Transport of Dangerous Goods, Manual of Tests and Criteria, 3rd revised edition, 1999.

[22] http://www.setaram.com/C80-Cells.htm.

[23] James Jr CW, Tamburello DA, Brinkman KS, Gray JR, Hardy BJ, Anton DL. Environmental exposure of $2 \mathrm{LiBH} 4+\mathrm{MgH} 2$ using empirical and theoretical thermodynamics. Int J Hydrogen Energy 2011;36:2471. 